Sains Malaysiana 50(12)(2021): 3467-3479

http://doi.org/10.17576/jsm-2021-5012-01

\title{
Impacts of Sea Temperature Rise on Rastrelliger kanagurta Potential Fishing Grounds in the Exclusive Economic Zone (EEZ) off South China Sea
}

(Kesan Kenaikan Suhu Laut terhadap Kawasan Perikanan Berpotensi Rastrelliger kanagurta pada Zon Ekonomi Eksklusif (EEZ) di Laut China Selatan)

\author{
KamaruZZaman, Y.N., Mustapha, M.A.* \& Ghaffar, M.A.
}

\section{ABSTRACT}

The Indian mackerel (Rastrelliger kanagurta) is one of the most commercially crucial epipelagic scombrid where it is caught in the Exclusive Economic Zone (EEZ) off the South China Sea (SCS). High demand for fisheries resources is a challenge for fishers to achieve optimal fish landing targets. By using R. kanagurta catch data, and high resolution satellite data of chl-a and SST (MODIS-Aqua) and SSH (AVISO) from 2018 together with boosted regression tree (BRT) model, this study aims to determine the impact of sea surface temperature (SST) increase on the potential catch of R. kanagurta based on temperature projection of IPCC-AR5-RCPS scenarios. BRT modelling result indicated that during the northeast monsoon (NEM), at elevated temperature of 1.80 and $2.60^{\circ} \mathrm{C}$ showed that the potential fishing grounds of $\mathrm{R}$. kanagurta increase in the area especially in the northern part of the EEZ. However, at elevated temperature of $3.30{ }^{\circ} \mathrm{C}$, the potential fishing areas was found to decrease along the coast of Peninsular Malaysia. Meanwhile, during southwest monsoon (SWM) and inter-monsoon transition, at temperature rise of $1.80,2.60$ and $3.30{ }^{\circ} \mathrm{C}$ showed a significant reduction in the potential fishing area of the R. kanagurta potential fishing grounds especially along the coast of the EEZ off SCS. Results indicated that changes in SST influenced suitability of habitat which affected the distribution of R. kanagurta. Understanding the impacts of temperature increase would contribute towards future sustainable fisheries resource management strategies.

Keywords: Boosted regression trees; exclusive economic zone; increase sea surface temperature; potential fishing ground; Rastrelliger kanagurta

\section{ABSTRAK}

Ikan kembung India (Rastrelliger kanagurta) adalah ikan epipelagik yang merupakan salah satu sumber marin komersil yang terpenting di perairan Zon Ekonomi Eksklusif(ZEE) Malaysia di Laut China Selatan (LCS). Permintaan tinggi terhadap sumber perikanan merupakan cabaran bagi nelayan untuk mencapai sasaran pendaratan ikan yang optimum. Kajian ini menggunakan data tangkapan ikan R. kanagurta, data satelit resolusi tinggi bagi klorofil-a (chl-a) dan suhu permukaan laut (SST) (MODIS-Aqua) serta ketinggian permukaan laut SSH (AVISO) pada tahun 2018 bersama model 'boosted regression trees' (BRT), bagi mendapatkan perhubungan antara taburan ikan R. kanagurta dengan faktor oseanografi dan menentukan taburan ikan R. kanagurta di perairan ZEE di LCS berdasarkan kenaikan suhu permukaan laut (SST) menggunakan pengunjuran suhu IPCC-AR5-RCPs. Hasil pemodelan BRT menunjukkan bahawa semasa monsun timur laut, kenaikan suhu 1.80 dan $2.60^{\circ} \mathrm{C}$ menunjukkan bahawa kawasan potensi penangkapan ikan $\mathrm{R}$. kanagurta meningkat terutamanya di bahagian utara ZEE. Namun, pada kenaikan suhu $3.30{ }^{\circ} \mathrm{C}$, kawasan penangkapan ikan yang berpotensi di zon tangkapan didapati berkurang di sepanjang perairan pantai di Semenanjung Malaysia. Sementara itu, semasa monsun barat daya dan monsun peralihan, pada kenaikan suhu 1.80, 2.60 dan $3.30^{\circ} \mathrm{C}$ menunjukkan penurunan yang signifikan di kawasan potensi penangkapan ikan R. kanagurta terutamanya di sepanjang perairan pantai ZEE di LCS. Hasil menunjukkan bahawa perubahan dalam SST mempengaruhi kesesuaian habitat yang mempengaruhi taburan ikan R. kanagurta. Memahami kesan peningkatan suhu dapat menyumbang kepada strategi pengurusan sumber perikanan yang lebih lestari pada masa depan.

Kata kunci: 'Boosted regression trees'; kawasan potensi penangkapan ikan; kenaikan suhu permukaan laut; Rastrelliger kanagurta; zon ekonomi eksklusif 


\section{INTRODUCTION}

Fisheries in the Exclusive Economic Zone (EEZ) off the South China Sea (SCS) are dominated by small pelagic fishes which can be grouped as scads, mackerels, anchovies, and sardines. Mackerels are among the most essential small pelagic production of the Southeast Asian countries contributing approximately $30 \%$ by quantity $(1,063,810$ metric ton) and $42 \%$ value in \$US/ metric ton. Mackerels that are predominantly caught in the SCS comprises of six species, namely: narrowbarred Spanish mackerel (Scomberomorus commerson), seerfishes (Scomberomorus spp.), Scomber mackerels nei (Scomber spp.), short mackerel (Rastrelliger brachysoma), Indian mackerel (Rastrelliger kanagurta), and other rastrelliger mackerels (Rastrelliger spp.) (SEAFDEC 2017). Rastrelliger kanagurta (Cuvier 1816) or also known as Indian mackerel is a highly migratory small pelagic fish which swims across the Exclusive Economic Zone (EEZ) between neighbouring countries depending on the oceanographic parameters and food availability. It is one of the most commercially important small pelagic fishery resources in Malaysia (Mansor et al. 1996). These species are fast-swimmers which usually schools in large aggregations and migrates seasonally and geographically in relation to the annual cycles of ocean productivity, reproductive cycles, ocean currents and circulation (Skjoldal et al. 2004).

Since 40 years ago, world fisheries production rates had declined almost $80 \%$ due to overfishing pressure, habitat change, pollution and climate change (FAO 2003). Sustainable marine resources need constant monitoring and effective fishing stock management. Scientific evidence has demonstrated that several important fish stocks are already fully exploited and even overexploited. A study conducted by Raja Bidin and $\mathrm{Ku}$ Kassim (2007) concluded that the mackerel resources in the SCS are already overexploited evidenced by the declining trends in the catch. Impacts of climate change also influence the fluctuation of stock abundance as well as changes in migration routes of these species. Threats of overexploitation and decreasing recruitment due to degradation and destruction of aquatic habitats also exacerbate these severe problems.

Cheung et al. (2013) stated that apparent changes in captured marine fisheries composition are related to changes in the ocean's temperature. Variations in sea surface temperature (SST) as a result of climate change has affected directly and indirectly on fisheries stock commercially. Direct impact can be seen on physiology, evolution of behaviour, growth, development, reproduction capacity, death and distribution. Meanwhile, the indirect effect has change productivity, structure and fish ecosystem composition where it depends on food and shelter (Brander 2010a). Climate change has an implication for biodiversity conservation and ecosystem (Rapport et al. 1998). Modelling approaches that are able to do simulation on species interaction with the environment is needed to understand the impact on species and community further. In climate change modelling, projected SST is a method that is often used to predict the effects of climate change on marine species (Dueri et al. 2014; Lehodey et al. 2012; Tseng et al. 2011).

Warming will affect regional variation and will create a population shift. Modelling spatial distribution and abundance of fisheries resources is necessary for assessing future impacts on population shift. Effects of elevated temperature on marine and freshwater ecosystem are very apparent with fast changes in fish distribution and plankton shift towards poleward (Beaugrand et al. 2002; Brander et al. 2003). Changes in distribution and productivity are expected to happen if warming continues and ice melting occurs (Drinkwater 2005). Small changes are expected to reduce fisheries production and fish stock (Brander \& Mohn 2004).

Globally since four decades ago, warming of the ocean has reached an average increment of $>01.0^{\circ} \mathrm{C}$ per decade (IPCC 2014a). According to Lam et al. (2020) the maximum potential catch of fish stocks in some tropical exclusive economic zones is projected to decline by up to $40 \%$ by the $2050 \mathrm{~s}$ under the RCP 8.5 emissions scenario, relative to the $2000 \mathrm{~s}$. SST is expected to increase at 1.80 until $3.30{ }^{\circ} \mathrm{C}$ with elevated temperature of 0.14 until 0.20 ${ }^{\circ} \mathrm{C}$ in Southeast Asia (IPCC 2014b). In addition to this, the high variability in stock abundance together with the migratory behavior of pelagic fishes pose a significant challenge in sustainable fisheries development and management (Brander 2013). The ability to determine the impact of SST increase and to predict the changes in fisheries resources in the long term is vital to guarantee the continuity of fisheries resources and contribute to effective management. This should be taken as a priority considering that the sustainability of the fishery resources would ensure food security, provide nutrition and food supply as well as improving the livelihoods of people in the region (Brander 2010b). Therefore, the objective of this paper is to determine the relationship between oceanographic factors with fish catch and to model the distribution of $R$. kanagurta in the EEZ waters off SCS using projected elevated SST based on IPCC AR5 RCP's scenarios. 


\section{MATERIALS AND METHODS}

\section{STUDY AREA}

The study was focused in Malaysia's EEZ fishing area off SCS at latitude $1^{\circ} 00$ to $8^{\circ} 00^{\prime} \mathrm{N}$ and longitude $102^{\circ} 00$ to $107^{\circ} 00^{\prime} \mathrm{E}$. The fishing area was divided into zones (A, B, C, and C2 zones) according to Malaysia's fishing zoning system (Figure 1). The potential fishing area in these zones was determined using Boosted Regression Trees (BRT) analysis. The impact of SST increase on the potential fishing grounds were modeled in these areas. Spatial distribution and the total size of potential fishing grounds at each fishing zones of the EEZ were determined based on the total area (Table 1).

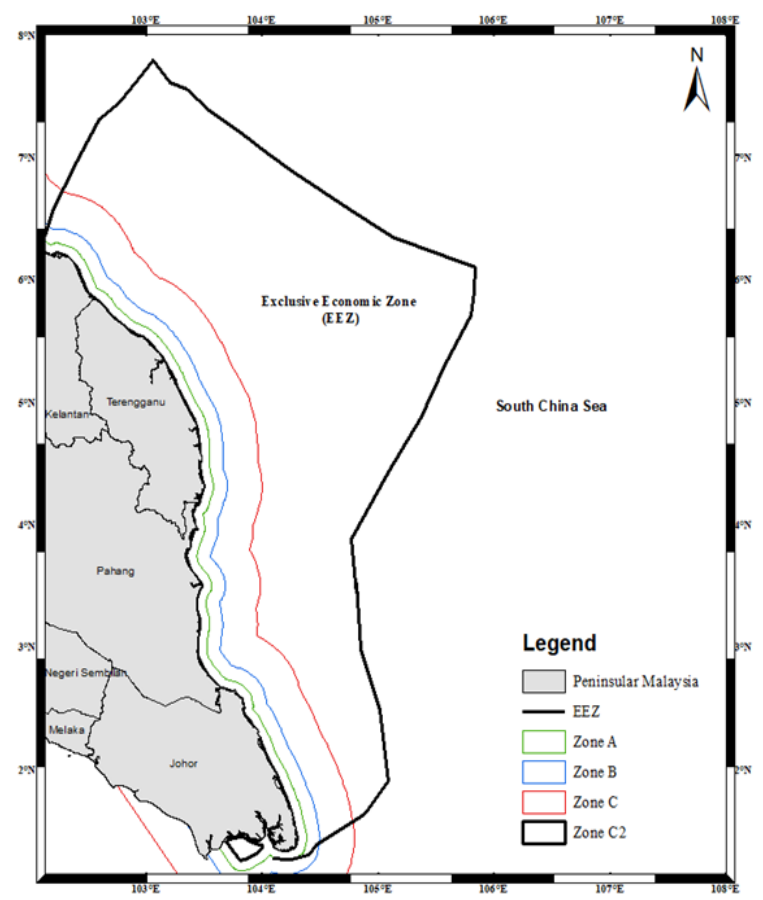

FIGURE 1. Peninsular Malaysia waters off South China Sea (SCS) according to the fishing zone systems for areas of capture fisheries. Black line indicates zone $\mathrm{C} 2$ until the border of the Exclusive Economic Zone (EEZ)

TABLE 1. Total area of each fishing zone in the EEZ waters off SCS

\begin{tabular}{lc}
\hline Fishing zone & Area $\left(\mathrm{km} \mathrm{sq}^{-2}\right)$ \\
\hline A & $6,604.4$ \\
B & $8,755.5$ \\
C & $22,699.1$ \\
C2 & $94,496.2$ \\
\hline
\end{tabular}




\section{FISHERIES DATA}

R. kanagurta purse seine fish catch data in the EEZ off SCS were provided by the Marine Fishery Resources Development and Management Department (MFRDMD). The data consisted of fishing location (latitude and longitude) and total fish catch in kilograms. Catch per unit effort (CPUE, $\mathrm{kg} \mathrm{m}^{-3}$ ) was calculated based on the size of the net $\left(\mathrm{m}^{3}\right)$, chloropyll-a (chl-a) data used as index of catch abundance. The catch data were divided into three categories (Andrade \& Garcia 1999; Zainuddin et al. 2008): (1) catch weight equal to zero (null catches), (2) catch weight greater than zero but lower than $127 \mathrm{~kg} \mathrm{~m}^{-3}$ (positive catches), and (3) catch weight greater than 127 $\mathrm{kg} \mathrm{m}^{-3}$ (high catches). The value of $127 \mathrm{~kg} \mathrm{~m}^{-3}$ represents the lower limit of the upper quartile of $R$. kanagurta catch weight greater than zero. To meet the objectives of this study, we focused our analyses on high catches of $R$. kanagurta in order to obtain the optimal relationship between fish distribution and oceanographic parameters.

\section{SATELLITE DATA}

Satellite images of chl-a and SST were obtained from Aqua-MODIS; meanwhile, sea surface height (SSH) was obtained from AVISO. The satellite images of the year 2018 were downloaded at $9 \times 9 \mathrm{~km}$ resolution (Table 2 ). In this study projected SST maps at 1.80, 2.60 and $3.30{ }^{\circ} \mathrm{C}$ were used to determine the impact of elevated SST on monthly potential fishing grounds of $R$. kanagurta from January 2018 to December 2018 derived using BRT model.

TABLE 2. Summary of oceanographic parameters used to forecast fishing grounds of the Indian mackerel (Rastrelliger kanagurta) in Malaysia's EEZ off SCS.

\begin{tabular}{lcccc}
\hline Oceanographic variables & $\begin{array}{c}\text { Temporal } \\
\text { resolution }\end{array}$ & $\begin{array}{c}\text { Spatial } \\
\text { footprint }\end{array}$ & Period & Data source \\
\hline $\begin{array}{l}\text { Chlorophyll-a (chl-a) } \\
\text { Sea surface temperature }\end{array}$ & Monthly & $9 \mathrm{~km}$ & 2018 & Aqua-MODIS \\
$\begin{array}{l}\text { (SST) } \\
\text { Sea surface height }\end{array}$ & Monthly & $9 \mathrm{~km}$ & 2018 & AVISO \\
(SSH) & Monthly & $9 \mathrm{~km}$ & 2018 & \\
\hline
\end{tabular}

\section{BRT MODELLING APPROACH}

Statistical modelling such as generalized linear model (GLM), generalized additive model (GAM) by Nurdin et al. (2017), Shaari and Mustapha (2018), Yusop et al. (2021) and presence-only modelling technique, maximum entropy (MaxEnt) Yusop et al. (2021) has been used to determine the distribution of $R$. kanagurta in relation with its environmental parameters (SST and chl-a) in the Southeast Asian waters. GAM is a semi-parametric extension of GLM, a conventional statistical approach by Hastie and Tibshirani (1990) and is proven to be a robust statistical approach in determining species distribution which allows data to recognized non-linearities in the relationship between habitat and species (Chambers \& Hastie 1992). Meanwhile, MaxEnt is a presence only data modelling. It only requires a set of known occurrences and predictor variables such as topographic, climatic, edaphic, biogeo-graphic and remotely sensed variables (Phillips \& Dudík 2008).
Study by Yusop et al. (2021) determined potential fishing grounds of $R$. kanagurta in the South China Sea using presence-absence data model (GAM) and presenceonly data model (MaxEnt) with two environmental variables (SST and chl-a). Results showed that the GAM model had higher prediction accuracy compared to MaxEnt. This is related to the sparse shortcoming in the selection of pseudo-absence samples. It produces lower predictions and less robust because the presence data does not represent the entire variety of species suitable to their habitat.

BRT is a complementary method that is well suited to data with complex interactions and can be summarized in ways that give powerful biological insight (Elith et al. 2008; James et al. 2013). Compared with the conventional multivariate regression method, the BRT is able to automatically identify the interactions between independent variables. BRT can increase predictive performance by reducing the over-learning, 
or over-fitting and in fitted BRT, and implementation of interactions between independent variables (De'ath 2007; Elith et al. 2008). According to Elith et al. (2008), BRT generalization error is relatively low and obtains better prediction accuracy on new data. The main features of the BRT model include i) the relationship between $R$. kanagurta occurrences with its environmental variables (chl-a, SST and SSH) and ii) prediction of the temporal and spatial distributions of $R$. kanagurta fishing grounds in the EEZ off SCS.

BRT was applied based on the presence/absence of fishing locations and corresponding environmental parameters; with high CPUE at (1) or lower CPUE at (0) as the response variable and SST, chl-a and SSH as predictor variables to model the distribution and forecasting of $R$. kanagurta. BRT combines the advantages of two statistical techniques: the decision trees and boosting and it can easily fit complicated linear relationship with multiple predictors (Elith et al. 2008; Leathwick et al. 2006). The boosting helps in optimizing the model accuracy through combine numbers of weak simple models into a reliable model. BRT was conducted using the formula (1):

$$
f_{M}(X)=\sum_{m=1}^{M} T_{m}\left(X, \gamma_{m}\right)
$$

where $\mathrm{X}$ is the predictor variable (SST, SSH or chl-a); $\mathrm{T}_{m}$ is the classification and regressions tree numbered $\mathrm{M}$ and $\gamma_{\mathrm{m}}$ is its parameter, representing the splitting points of the trees and the values assigned to each terminal nodes. The solving of $\gamma$ is also the learning process of the decision tree $\mathrm{T}_{m}$.

Performance of predictions was assessed on the basis of two statistical criteria: cross-validation and AUC (area under the receiver operating curve) which were calculated based on the data prepared for evaluation. Cross-validation is a technique for assessing how the results of a statistical analysis generalize to an independent data set while still using all of the data for model development. It involves two separate data, training and validation. BRT model was run through ten-fold crossvalidation to evaluate the robustness and to decide on the number of decision trees with the minimum, average estimation deviation as the optimum number of trees, then use all of the training data to establish the fishing ground forecasting model with the optimum number of trees. Test data were then used to validate the estimated model. The model output was then categorized into binary values using a selected threshold. A threshold of predicted fishing grounds at $\geq 127 \mathrm{~kg} \mathrm{~m}^{-3}$ from the BRT model was applied. The environmental data of each month from January to
December 2018, were substituted into the forecast model to calculate the monthly averaged probability of having high potential fishing ground.

\section{RESULTS}

BRT model used three main environmental factors of SST, chl-a and SSH from the areas of high fishing catch to produce the pelagic habitat fishing grounds. BRT analysis suggested that all environmental variables used were closely related to the fishing grounds. Predicted fishing grounds showed high predicted probability for SSH at ranges from 1.1-1.3 m, SST ranges from 29.0-32.0 ${ }^{\circ} \mathrm{C}$ and chl-a ranges from $0.25-0.60 \mathrm{mg} \mathrm{m}^{-3}$. Predicted fishing grounds from the BRT model indicated AUC of 0.752 and 0.749 derived from cross-validation and test data set (actual fishing data), respectively. According to Hosmer and Lemeshow (2000), AUC values of $>0.9$ show excellent performance, $0.8-0.9$ is excellent and 0.7-0.8 satisfactory. Meanwhile, AUC 0.5 indicates that predictions are no better than random.

The impact of SST increase on $R$. kanagurta distribution in January, February and March 2018 was demonstrated in Figure 2. In January, areas of high potential fishing grounds showed small distribution and concentrated along the coast of EEZ especially in the northern part of Peninsular Malaysia. In the scenario of elevated temperature of 1.80 and $2.60{ }^{\circ} \mathrm{C}$, high catches in January were found to increase in the north part of the fishing zone especially in the zone $\mathrm{C}$ and $\mathrm{C} 2$ with an increase of $11.8,5.2,9.4$ and $13.3 \%$ accordingly. But in elevated temperature of $3.30{ }^{\circ} \mathrm{C}$, the potential fishing areas was found to decrease in along the coast of Peninsular Malaysia especially in zone A, B and C at 8.8, 13.6 and $12.1 \%$ accordingly. However, there was a small increment in the catchment zone in zone C2 $(2.4 \%)$.

In February, small area of distribution was concentrated along the EEZ coast ( $\leq 12$ nautical miles). A temperature rises of $1.80{ }^{\circ} \mathrm{C}$ showed an increase in each fishing zone at $26.3 \%$ (zone A), $54.2 \%$ (zone B), $79.4 \%$ (zone C) and 19.6\% (zone C2) especially in the northern part of the EEZ. Meanwhile, increase in temperature of $2.60{ }^{\circ} \mathrm{C}$ also showed a small decrease in the catch area in all waters of the fishing zone indicating a decline of 4.2, 7.2 and $4.3 \%$ accordingly except in zone C2. Increase in temperature at $3.30{ }^{\circ} \mathrm{C}$ also showed a reduction of 39.9 , 40.1 and $36.7 \%$, especially in the northern area in the zone $\mathrm{A}, \mathrm{B}$ and $\mathrm{C}$. However, in zone $\mathrm{C} 2$ development of the potential fishing ground area occurred with increase temperature of 2.60 and $3.30{ }^{\circ} \mathrm{C}$ indicating an increase of 31.7 and $0.3 \%$ accordingly in all fishing zone across Peninsular Malaysia. 
March also showed a small distribution of concentrated potential fishing areas along the coast $(\leq$ 12 nautical miles) of the EEZ. At temperature rise of 1.80 ${ }^{\circ} \mathrm{C}$, the potential fishing area was found to increase in each fishing zone along the coast of EEZ at $6.4 \%$ (zone A), $28.6 \%$ (zone B), $72.9 \%$ (zone C) and $27.1 \%$ (zone C2). However, at temperature increase of 2.60 and 3.30
${ }^{\circ} \mathrm{C}$, the potential catch area showed a reduction in most catch zone along the coast of EEZ with a decrease of 28.5 and $13.9 \%$ in zone A, 45.8 and $24.3 \%$ in zone B, 70.5 and $13.0 \%$ in zone $\mathrm{C}$ and 19.8 and $6.2 \%$ in zone $\mathrm{C} 2$ accordingly. A temperature rises of $3.30{ }^{\circ} \mathrm{C}$ also resulted in reduction of potential fishing area across the EEZ waters. The potential fishing area is also observed to shift outside of the EEZ areas.

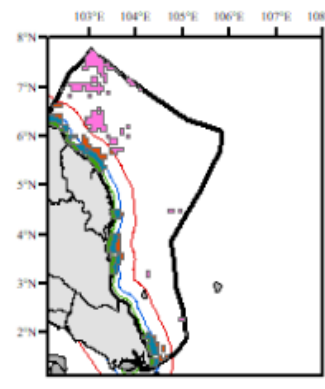

Jan 2018

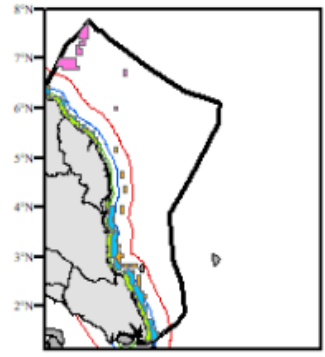

Feb 2018

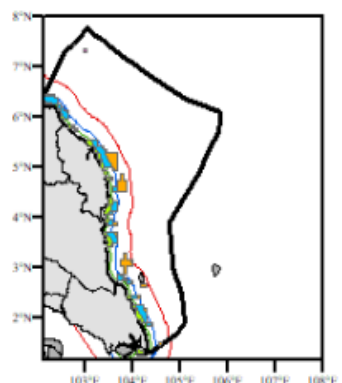

March 2018

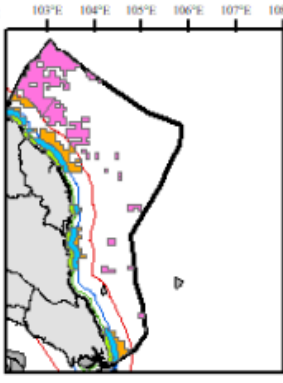

$+1.8$

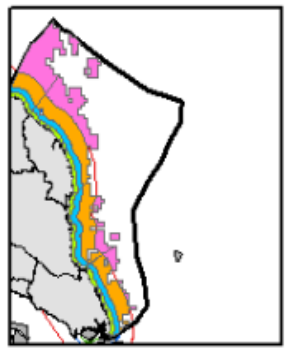

$+1.8$

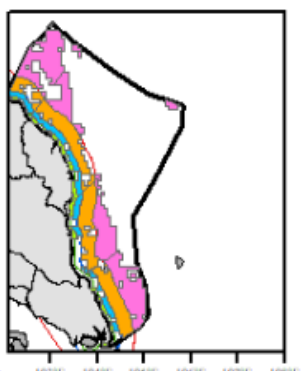

$+1.8$

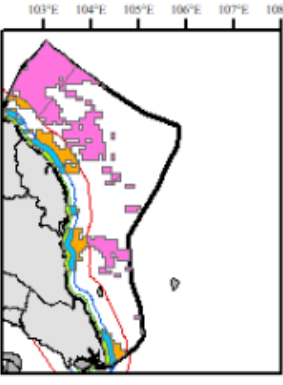

$+2.6$

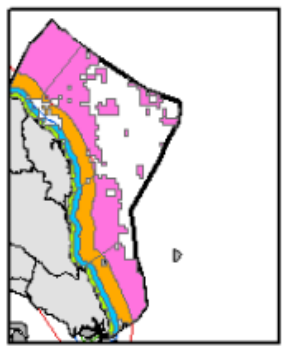

$+2.6$

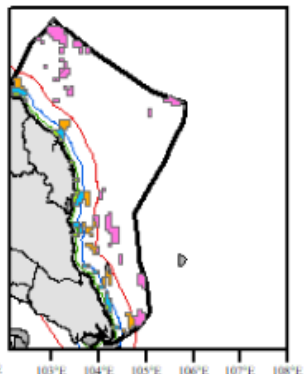

$+2.6$

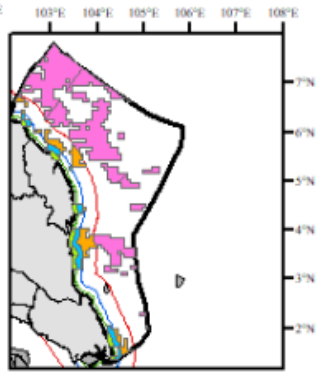

$+3.3$

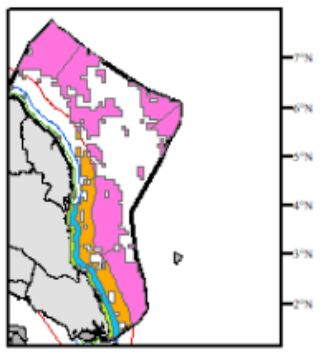

$+3.3$

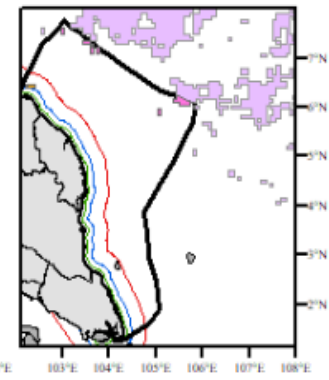

$+3.3$

FIGURE 2. The predicted potential fishing area of $R$. kanagurta in January 2018, February 2018 and March 2018; and predicted potential fishing area based on projected elevated SST at $1.80 ; 2.60 ;$ and $3.30{ }^{\circ} \mathrm{C}$, up to the next 30 years in the EEZ off SCS based on the fishing zone systems

In April, the predicted areas of high potential fishing grounds occurred along the coast of the EEZ (zone A, B and C) (Figure 3). Meanwhile, zone C2 indicated lesser potential especially in the middle part of Peninsular Malaysia. High potential fishing area decreased with elevated SST at $1.80^{\circ} \mathrm{C}$ particularly along the coastal region (zone A, B and C) with a reduction of 25.5, 19.6 and $3.4 \%$, respectively. However, in zone C2 potential fishing ground was observed to increase about $15.4 \%$ especially in the northern part of the EEZ. As SST increased at $2.60{ }^{\circ} \mathrm{C}$ 
the potential fishing grounds had a significant reduction of 50.6, 71.5, 53.1 and $23.9 \%$ along the coast of the EEZ. Further increase of temperature at $3.30{ }^{\circ} \mathrm{C}$ resulted in the decrease of the potential fishing area along the coast of the EEZ from 1 to $12 \%$ and it was observed to shift outside of the EEZ areas.

Entering May, the areas with potential catches increased and concentered more widely especially in the southern areas. However, with the increased temperature at $1.80{ }^{\circ} \mathrm{C}$, the potential fishing ground was found to decrease along the coast of the EEZ with a reduction of 63.1 (zone A), 52.6 (zone B), 36.5 (zone C) and 11.2\% (zone C2). Meanwhile, a further increase in temperature at 2.60 and $3.30{ }^{\circ} \mathrm{C}$ indicated overall potential fishing area drastically reduced from 7.4 to $24.7 \%$.

In June, the high potential fishing area was observed to be intensified in each of the fishing zones of the EEZ. However, with the increase in temperature at 1.80, 2.60 and $3.30{ }^{\circ} \mathrm{C}$ it was found that the potential fishing area along the coast of the EEZ decreased drastically from 0.8 to $94.5 \%$ especially in zone A $(83.8 \%)$, zone B $(94.5 \%)$ and zone $\mathrm{C} 2(93.5 \%)$. At an elevated temperature of 1.80 , 2.60 and $3.30{ }^{\circ} \mathrm{C}$ the potential fishing area was observed to decline drastically and observed to be shifted away from the EEZ areas.

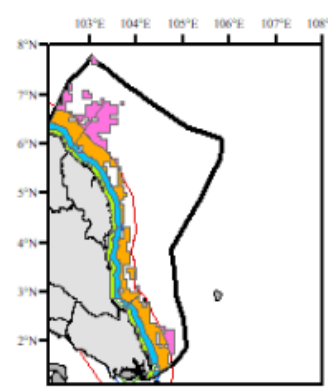

April 2018

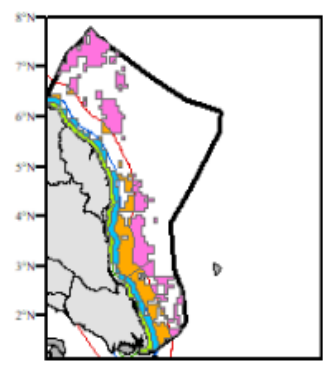

May 2018

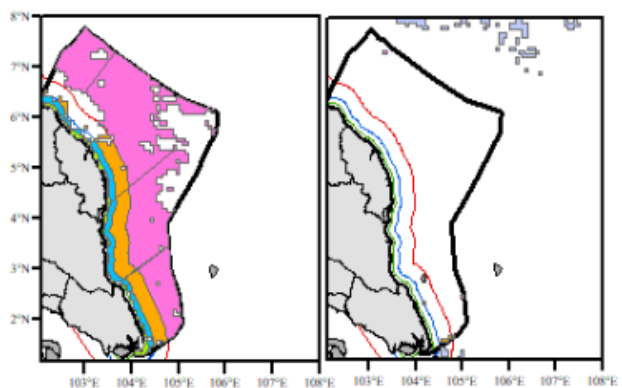

June 2018

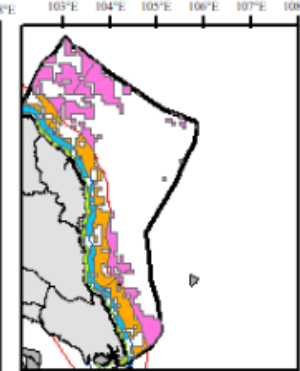

$+1.8$

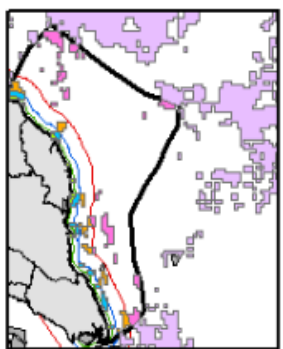

$+1.8$

$+1.8$

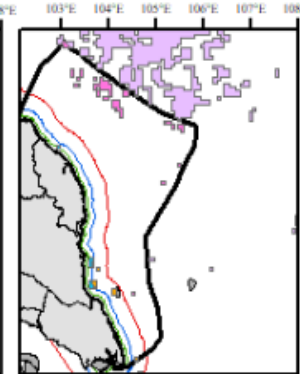

$+2.6$

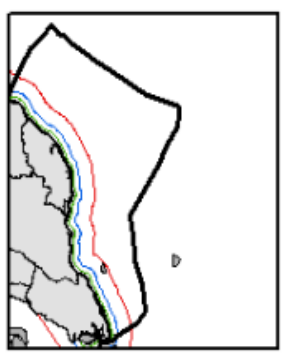

$+2.6$

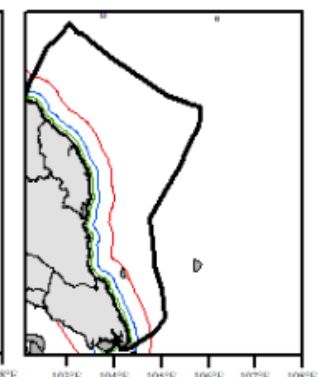

$+2.6$

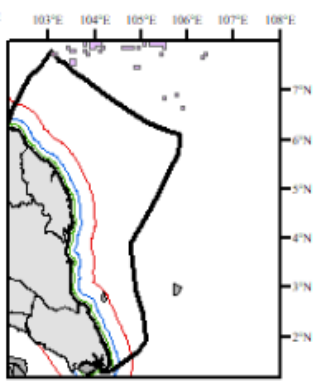

$+3.3$
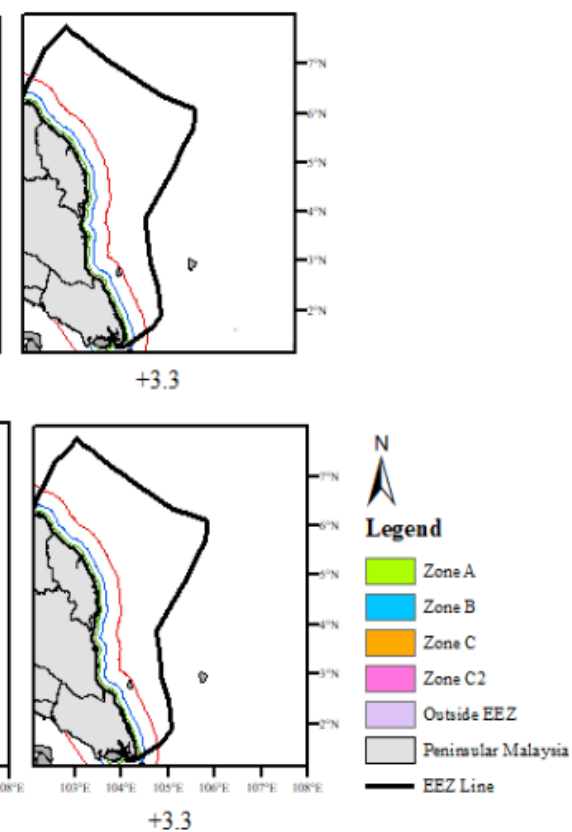

FIGURE 3. The predicted potential fishing area of R. kanagurta in April 2018, May 2018 and June 2018; and predicted potential fishing area based on projected elevated SST at $1.80 ; 2.60$; and $3.30^{\circ} \mathrm{C}$, up to the next 30 years in the EEZ off SCS based on the fishing zone systems 
In July, high potential fishing grounds were found to be intensified along the coastal waters of Peninsular Malaysia (zones A, B and C). However, the potential fishing area in the offshore (zone $\mathrm{C} 2$ ), was observed to decline (Figure 4). Increase in temperature at $1.80,2.60$ and $3.30{ }^{\circ} \mathrm{C}$ in July showed a reduction in the area of potential catch in each zone with a decrease from 4.3 to $82.7 \%$ especially in zone A (71.9\%), zone B (82.7\%) and zone C (73.1\%) except in the southern area.

In August, highest potential fishing grounds was predicted along the coast and offshore areas off EEZ. At elevated SST of $1.80^{\circ} \mathrm{C}$, predicted potential fishing areas intensified at the southern areas especially in zone C2 with an increase of $13.7 \%$. Lower predicted potential fishing areas occurred in the northern areas, especially in zone $\mathrm{A}, \mathrm{B}$ and $\mathrm{C}$ with a reduction of $31.9,30.8$ and $21.1 \%$ accordingly. Further increase of SST at 2.60 and
$3.30{ }^{\circ} \mathrm{C}$ resulted in a drastic decline of potential fishing grounds (7.4 to $52.2 \%)$ with only small areas left along the southern coast.

In September, the high potential fishing area was found to be more widely distributed in the EEZ areas compared to in July and August. However, the potential fishing area of $R$. kanagurta was found to decrease significantly at elevated temperature of 1.80, 2.60 and 3.30 ${ }^{\circ} \mathrm{C}$ in each fishing zones along the coast of the EEZ. At temperature rise of $1.80^{\circ} \mathrm{C}$, the potential fishing area was found to be reduced by 52.5 to $81.7 \%$. Meanwhile, when the temperature increase to $2.60{ }^{\circ} \mathrm{C}$ the potential fishing area decreased by 1.5 to $15.8 \%$ and at further temperature rise of $3.30{ }^{\circ} \mathrm{C}$ resulted in a decrease of the potential fishing area by 0.2 to $6.7 \%$. In August and September potential fishing areas was also found to be reduced at the increase of temperature at $1.80,2.60$ and $3.30{ }^{\circ} \mathrm{C}$ and the potential fishing ground moves beyond the EEZ border.

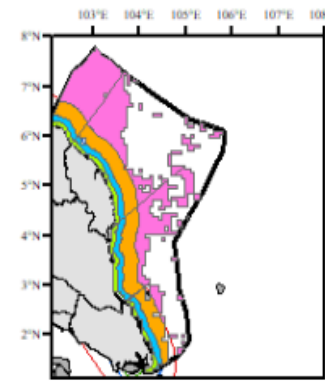

July 2018

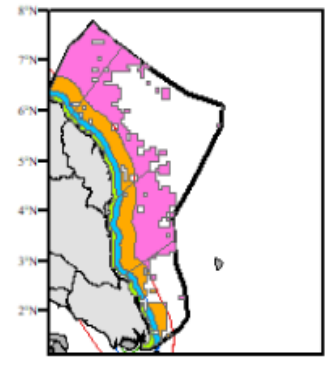

Aug 2018

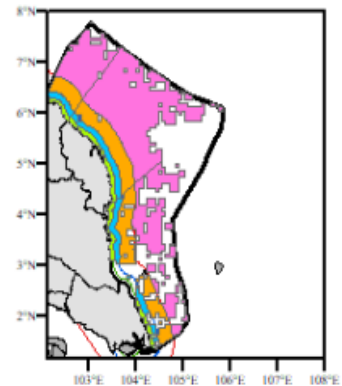

Sept 2018

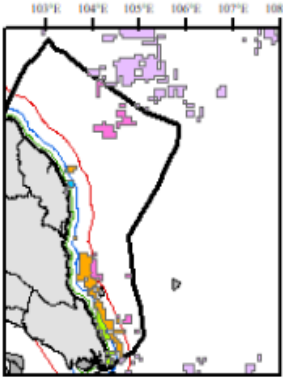

$+1.8$

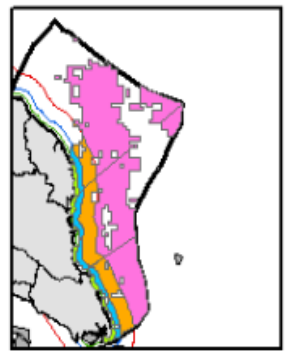

$+1.8$

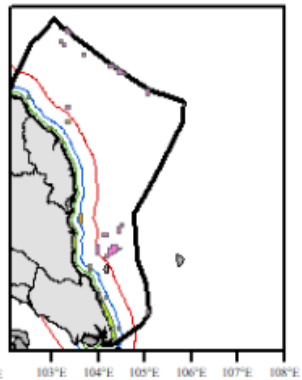

$+1.8$

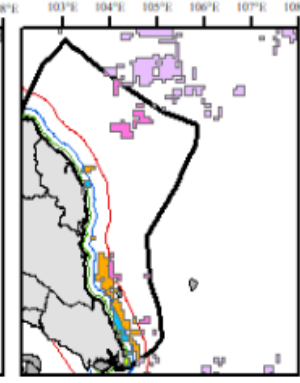

$+2.6$

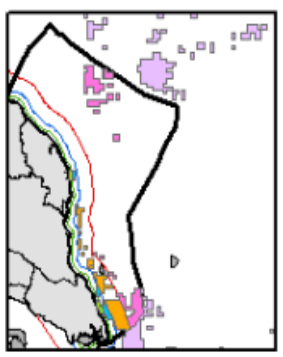

$+2.6$

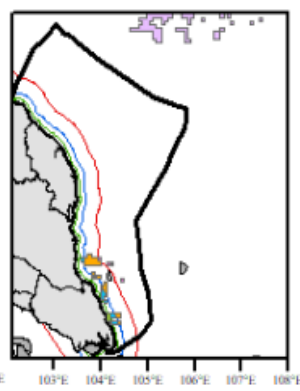

$+2.6$

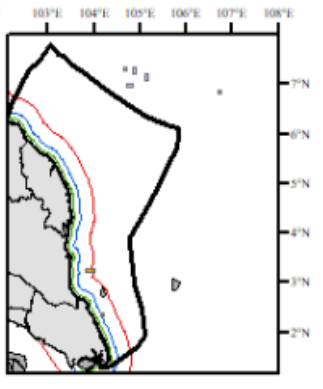

$+3.3$
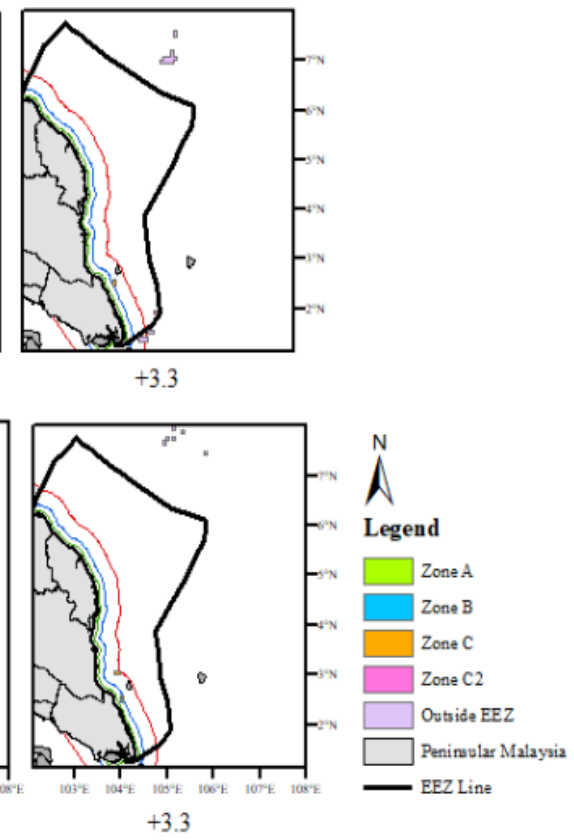

FIGURE 4. The predicted potential fishing area of R. kanagurta in July 2018, August 2018 and September 2018; and predicted potential fishing area based on projected elevated SST at 1.80; 2.60; and $3.30^{\circ} \mathrm{C}$, up to the next 30 years in the EEZ off SCS based on the fishing zone systems 
In October, the high potential fishing ground was predicted to occur at most of the EEZ region, but increased of SST at 1.80, 2.60 and $3.30{ }^{\circ} \mathrm{C}$ further reduced the potential fishing areas (Figure 5). At temperature rise of $1.80^{\circ} \mathrm{C}$, the potential fishing area was found to decreased drastically at 83.8 (zone A), 94.5 (zone B), 93.5 (zone C) and $44.1 \%$ (zone $\mathrm{C} 2$ ). Further increase in temperature of 2.60 and $3.30{ }^{\circ} \mathrm{C}$, the potential fishing area decreased by 0.8 to $2.8 \%$ and it was observed that there were no longer potential fishing areas in the waters of Peninsular Malaysia and outside of the EEZ area.

The distribution of high potential fishing areas in November showed the same distribution pattern as in October but the catch potential areas are more widespread up to the EEZ border. Increase in SST of 1.80, 2.60 and $3.30{ }^{\circ} \mathrm{C}$, resulted in a decrease of potential fishing grounds of 36.8 to $63.3 \%, 6.2$ to $24.1 \%$ and 0.4 to $10.7 \%$, respectively, except in the southern area. In
November, at elevated temperature of $1.80^{\circ} \mathrm{C}$, the potential fishing areas were observed to move outside of the EEZ areas and at a temperature rise of 2.60 and $3.30{ }^{\circ} \mathrm{C}$ it was found that the potential fishing area had shifted beyond the EEZ border.

In December, the potential fishing area was found to be significantly reduced and the high potential area was limited to the coastal areas (zones A, B and C) along the EEZ waters. Increase in temperature at $1.80^{\circ} \mathrm{C}$ showed that potential fishing areas in zone A and zone B especially in the northern area, was reduced by 14.9 and $14.3 \%$ but in zone $\mathrm{C}$ and $\mathrm{C} 2$, the potential fishing areas increased by 19.4 and $45.7 \%$, respectively, significantly in the southern area. However, increase in temperature of 2.60 and $3.30{ }^{\circ} \mathrm{C}$ showed a reduction in the potential fishing grounds by 7.8 to $65.2 \%$ along the coast of the EEZ and the potential fishing grounds was observed to occur outside of the EEZ.

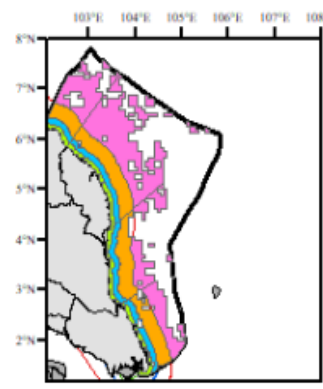

Oct 2018

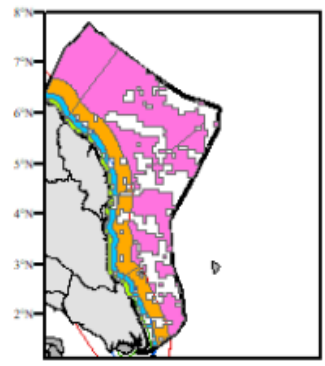

Nov 2018

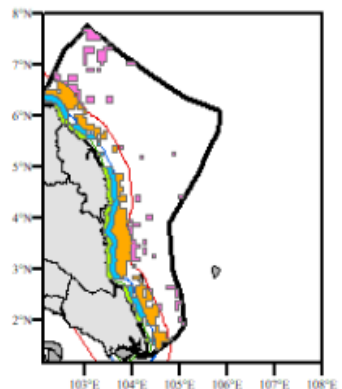

Dec 2018

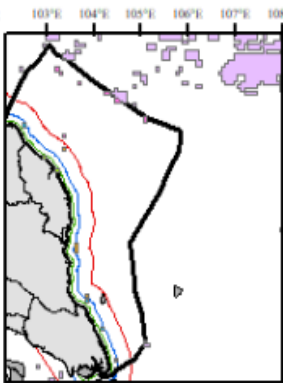

$+1.8$

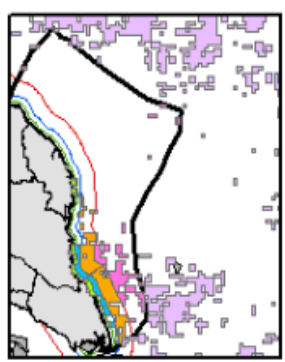

$+1.8$

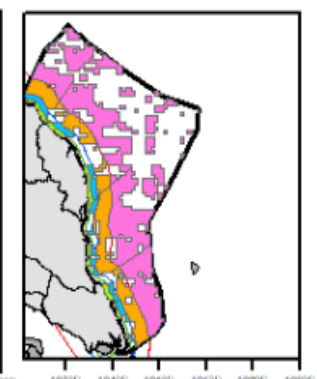

$+1.8$

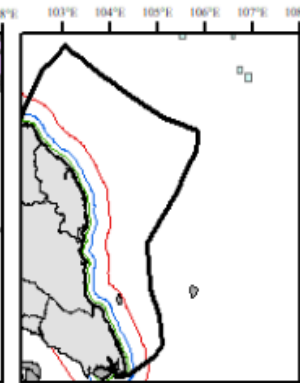

$+2.6$

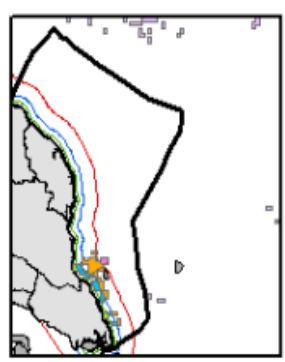

$+2.6$



$+2.6$

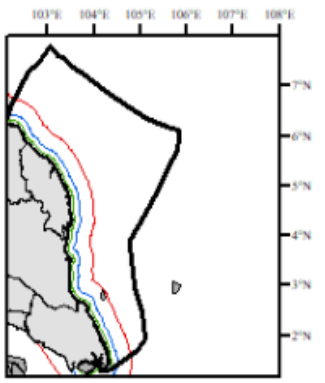

$+3.3$

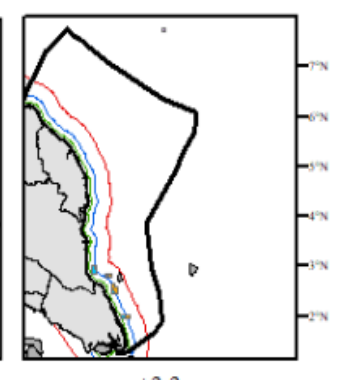

$+3.3$

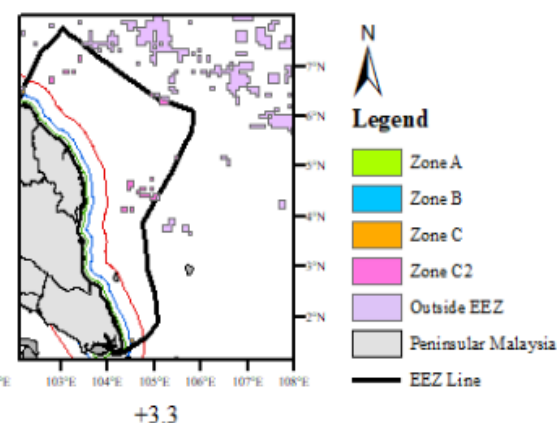

FIGURE 5. The predicted potential fishing area of R. kanagurta in October 2018,

November 2018 and December 2018; and predicted potential fishing area based on projected elevated SST at $1.80 ; 2.60$; and $3.30^{\circ} \mathrm{C}$, up to the next 30 years in the EEZ off SCS based on the fishing zone systems 


\section{DISCUSSION}

SST is one of the vital environmental parameters which is often used in determining the relationship between oceanographic conditions with the fish distribution. SST controls the physiology of an organism such as spawning period, aggregation and migration (Solanki et al. 2005). SST affects the metabolic rate and alters the level of fish activity. SST is also often used as an indicator of ocean productivity where it affects the development of phytoplankton (Tang et al. 2003).

Climate change has caused variation in marine factors such as SST, sea level rise, $\mathrm{pH}$, rainfall, ice melting at the pole, and change in wind speed and directions (Hollowed et al. 2013). This in turns changes the biology of organism and phenology (Edwards \& Richardson 2004), spatial distribution and abundance, community structure (Simpson et al. 2011), trophic interactions (Harley 2011) and finally fisheries resources (Sumaila et al. 2011). Thus, climate change will cause an increase in SST and it will affect the distribution and abundance of fish populations. The most significant impact of elevated temperature on fish population is in the change of their distribution pattern. Temperatures as small as $1{ }^{\circ} \mathrm{C}$ can have an effect on their geographical distribution (Perry et al. 2005). The range limit may increase or decrease depending on the heat tolerance of a species. Most tropical marine fish have extensive latitude range capable of further extending the temperature gradient up to $3-4{ }^{\circ} \mathrm{C}$. Therefore, it is important to understand the relationship between fish distribution with its environments in order to identify the favourable habitat for fisheries stock management (Giddings et al. 2006). That favourable habitat is related to the dynamics of ocean's biological and physical conditions such as chl-a concentrations, SST, salinity, depth, wind and current. The BRT model extracted the optimum combination of the three environmental factors (SST, chl-a and SSH) from the areas of high catch to predict the probability of $R$. kanagurta fishing grounds. $R$. kanagurta were found in strong association with $\mathrm{SSH}$ range of $1.1-1.3 \mathrm{~m}, \mathrm{SST}$ of $29.0-32.0^{\circ} \mathrm{C}$ and chl-a ranges of $0.3-0.6 \mathrm{mg} \mathrm{m}^{-3}$. Results of a recent study have also shown that the most suitable SST for R. kanagurta in SCS ranges between $29.2-31.5^{\circ} \mathrm{C}$ (Nadira et al. 2019; Shaari \& Mustapha 2018).

BRT modeling showed that in 2018, during the NEM from December to March, the potential fishing grounds of R. kanagurta was less distributed compared to during the southwest monsoon (SWM). However, during $\mathrm{NEM}$, at elevated temperature of $1.80{ }^{\circ} \mathrm{C}$ in January and December 2018, potential fishing zone area increase especially in zone $C$ and $C 2(\geq 12$ nautical miles to the EEZ border) at the northern part of the EEZ. Meanwhile in February and March 2018, potential fishing zone area increases along the coastal waters of the EEZ especially in zone B and C. Meanwhile, at elevated temperature of 2.60 and $3.30^{\circ} \mathrm{C}$ a reduction in the area of potential catch occurred except in January. The elevated temperature of $2.60{ }^{\circ} \mathrm{C}$ showed an increased area of potential fishing zone in the northern part. However, at elevated temperature of $3.30{ }^{\circ} \mathrm{C}$, the potential fishing areas was found to decrease in zone $\mathrm{A}, \mathrm{B}$ and $\mathrm{C}$ along the coast of Peninsular Malaysia. During SWM high distribution of $R$. kanagurta was found along the coastal areas of Peninsular Malaysia and inter-monsoon transitions seasons. However, at elevated temperatures of 1.80 , 2.60 and $3.30{ }^{\circ} \mathrm{C}$ during this monsoon season (April to November) showed a significant reduction in the potential fishing areas of the R. kanagurta especially along the coast of the EEZ.

It was observed that change in temperature above or below the optimum temperature range would result in the potential fishing grounds to be unsuitable for the $R$. kanagurta habitat. Fish migration occurs when SST rises and there will be a shift towards colder or deeper areas. This migration resulted in a reduction in the distribution of $R$. kanagurta in the EEZ off SCS. A study from Nurdin et al. (2017) also showed that $R$. kanagurta moved south (away from the waters of the Spermonde Islands), heading to areas with suitable temperatures.

The increase in potential area at temperature rises of $1.80{ }^{\circ} \mathrm{C}$ during NEM was seen to occur mainly in the northern part of the EEZ where it is influenced by the characteristics of the waters in the Gulf of Thailand (Tan et al. 2002). These potential fishing ground areas were affected by the NEM winds where cooler SST and processes such as upstream flow occurs at the east coast of the Gulf of Thailand and Vietnam (Akhir et al. 2014). Sea surface heating and weak sea surface wind during NEM resulted in the development of stratification. This process was found to be very suitable for fish feeding areas, as the water in the cooler bottom layer carries nutrient-rich water to the surface of the sea. These nutrient-rich waters will attract phytoplankton to accumulate and contributes to high concentrations of chl-a (Palenzuela et al. 1998). This also encourages a stable environment for fishes to feed and breed. Based on R. kanagurta preferred range of SST, when the temperature increase, SST in this area becomes more suitable than the colder current temperature conditions. Increase temperatures, especially at $1.80{ }^{\circ} \mathrm{C}$ were found to help create environmental conditions that encourage fish aggregations. 
The positive impact of elevated temperature is also expressed in a study from Sabatés et al. (2012) for bluefish (Pomatomus saltatrix) in the Northwest Mediterranean and Atlantic Ocean (Callihan et al. 2008). Like bluefish, tropical fish species will be able to adapt positively to changing environmental conditions (Lasram \& Mouillot 2009). However, the positive distribution trend for pelagic fish is expected to stop and biomass will begin to decline even if fishing efforts are controlled. This indicates that environmental conditions will be less suitable in the area due to increased temperature and productivity. A study by Lehodey et al. (2012) on the skipjack tuna (Katsuwonus pelamis) in the western Pacific Ocean using the IPCC-AR4 scenario also showed a positive impact from rising SST due to climate change. Biomass and catch of skipjack tuna were predicted to increase until 2050 as the feeding and spawning habitat becomes more suitable for the species. However, after 2060, the fish biomass and fish catch will begin to decrease due to the formation of the hot pool resulting from constant global warming which causes the area to be less suitable for feeding and spawning.

During SWM, the increase in temperature was too high resulting in unsuitable habitat for $R$. kanagurta. Marine fish species have different responses depending on the environmental conditions that suit their habitat (Fulton 2011; Gangoso et al. 2013). A study from Vivekanandan (2011) found that increase SST along Indian waters showed the advantage for $R$. kanagurta in finding suitable temperatures especially in northern and eastern latitudes, by extending their distribution boundaries and forming more extensive fishing grounds in coastal areas.

However, if SST in the southern latitudes rises above the optimal physiological threshold of $R$. kanagurta, it is likely that these fishing grounds will move far from southern latitudes and reduce potential fishing areas along the southwest and southeastern coastal waters of India. Warming of seawater also causes fish species to move into deeper waters, and R. kanagurta was found in deeper waters over the past two decades along Indian waters. According to Weimerskirch et al. (2012) some species will benefit from the shift. But in most cases, these changes will change the peak season of catching and distribution of predator and prey relationships.

Fish have the ability to change their behaviour in response to changes in the environment (Bellido et al. 2008). One of the fish's responses to temperature changes is migration. Migration for food can also change the habitat of the pelagic fish. As a migratory species, R. kanagurta have the ability to adapt quickly to the environment and are expected to grow in line with climate change although they have a tendency to change migration patterns according to feeding and spawning areas (Hughes et al. 2003). Thus, reducing fishing pressure is one of the best approaches in increasing the capacity of fish stocks in order to face the impact of climate change. Efforts to reduce these capture stresses are crucial in addressing these issues related to the sustainability of tropical marine fisheries and ecosystems by taking into account the impact of climate change as one of the anthropogenic components (Vivekanandan 2013). Information from this study can provide an understanding of the mechanisms that link climate change with the distribution of R. kanagurta in order to be used as necessary information in the planning and management of fishery resources in the future.

\section{CONCLUSION}

The scenario of sea level rise based on IPCC AR5 RCPs in this study has shown that at increase in temperature of $1.80{ }^{\circ} \mathrm{C}$ resulted in an increase in the potential fishing grounds of $R$. kanagurta especially in the northern part of the EEZ during NEM (January and December 2018). Meanwhile in March and April 2018, potential fishing area was observed to increase along the coastal waters of Peninsular Malaysia. Elevated temperature of $2.60{ }^{\circ} \mathrm{C}$ also showed an increased area of potential fishing zone, especially in the northern part. However, at elevated temperature of $3.30{ }^{\circ} \mathrm{C}$, the potential fishing areas was found to decrease along the coast of Peninsular Malaysia especially in zone A, B and C. Meanwhile, during SWM and inter-monsoon transition (April to November), at elevated temperature of $1.80,2.60$ and $3.30^{\circ} \mathrm{C}$ a significant reduction occurred in the potential fishing area of the $R$. kanagurta especially along the coast of the EEZ off SCS. Approaches used in this study were able to model the impact of SST increase on $R$. kanagurta potential fishing grounds. This work contributes to the overall scope of sustainability in securing future fisheries resources.

\section{ACKNOWLEDGEMENTS}

The authors would like to thank the NASA Goddard Space Flight Center for the MODIS-Aqua Level 1 data used in this study and SEAFDEC for supplying the fisheries data. This work has been supported by the Ministry of Science, Technology and Innovation Fund (04-01-02SF0753).

\section{REFERENCES}

Akhir, M.F., Zakaria, N.Z. \& Tangang, F. 2014. Intermonsoon variation of physical characteristics and current circulation along the coast of Peninsular Malaysia. International Journal of Oceanography 2014: 1-9. 
Andrade, H.A. \& Garcia, C.A.E. 1999. Skipjack tuna fishery in relation to sea surface temperature off the southern Brazillian coast. Fisheries Oceanography 8(4): 245-254.

Beaugrand, G., Reid, P.C., Ibanez, F., Lindley, J.A. \& Edwards, M. 2002. Reorganization of North Atlantic marine copepod biodiversity and climate. Science 296(5573): 1692-1694.

Bellido, J.M., Brown, A.M., Dalavanis, V.D., Giráldez, A., Pierce, G.J., Iglesias, M. \& Palialexis, A. 2008. Identifying essential fish habitat for small pelagic species in Spanis Mediterranean waters. Hydrobiologia 612(2008): 171-184.

Brander, K. 2013. Climate and current anthropogenic impacts on fisheries. Climatic Change 119(1): 9-21.

Brander, K. 2010a. Impacts of climate change on fisheries. Journal of Marine Systems 79(3-4): 389-402.

Brander, K.M. 2010b. Cod Gadus morhua and climate change: Processes, productivity and prediction. Journal of Fish Biology 77(8): 1899-1911.

Brander, K.M. \& Mohn, R.K. 2004. Effect of the North Atlantic oscillation on recruitment of Atlantic cod. Canadian Journal of Fisheries and Aquatic Sciences 61(9): 1558-1564.

Brander, K.M., Blom, G., Borges, M.F., Erzini, K., Henderson, G., MacKenzie, B.R., Mendes, H., Ribeiro, J., Santos, A.M.P. \& Toresen, R. 2003. Changes in fish distribution in the eastern North Atlantic: Are we seeing a coherent response to changing temperature? In International Council of the Exploration of the Sea (ICES) Marine Science Symposia. 219: 261-270.

Callihan, J.L., Takata, L.T., Woodland, R.J. \& Secor, D.H. 2008. Cohort splitting in bluefish, Pomatomus saltatrix, in the US mid-Atlantic Bight. Fisheries Oceanography 17(3): 191-205.

Chambers, J.M. \& Hastie, T.J. 1992. Statistical Models. London: Chapman and Hall. pp. 1-608.

Cheung, W.W.L., Watson, R. \& Pauly, D. 2013. Signature of ocean warming in global fisheries catch. Nature 497(7449): 365-368.

De'Ath, G. 2007. Boosted trees for ecological modelling and prediction. Ecology 88(1): 243-251.

Drinkwater, K.F. 2005. The response of Atlantic cod (Gadus morhua) to future climate change. ICES Journal of Marine Science 62(7): 1327-1337.

Dueri, S., Bopp, L. \& Maury, O. 2014. Projecting the impacts of climate change on skipjack tuna abundance and spatial distribution. Global Change Biology 20(3): 742-753.

Edwards, M. \& Richardson, A.J. 2004. Impact of climate change on marine pelagic phenology and trophic mismatch. Nature 430(7002): 881-884.

Elith, J., Leathwick, J.R. \& Hastie, T. 2008. A working guide to boosted regression trees. Journal of Animal Ecology 77(4): 802-813.

FAO. 2003. The Ecosystem Approach to Marine Capture Fisheries. Food and agriculture organization technical guidelines for responsible fisheries. p. 112.

Fulton, E.A. 2011. Interesting times: Winners, losers, and system shifts under climate change around Australia. ICES Journal of Marine Science 68(6): 1329-1342.

Gangoso, L., Márquez-Ferrando, R., Ramírez, F., Gomez-Mestre, I. \& Figuerola, J. 2013. Understanding phenotypic responses to global change. BioEssays 35(5): 491-495.
Giddings, E.M., Brown, L.R., Short, T.M. \& Meador, M.R. 2006. Relation of fish communities to environmental conditions in urban streams of the Wasatch Front, Utah. Western North American Naturalist 66(2): 155-168.

Harley, C.D.G. 2011. Climate change, keystone predation, and biodiversity loss. Science 334(6059): 1124-1127.

Hastie, T.J. \& Tibshirani, R.J. 1990. Generalised Additive Models. New York: Chapman and Hall. p. 352.

Hollowed, A.B., Barange, M., Beamish, R.J., Brander, K., Cochrane, K., Drinkwater, K., Foreman, M.G.G., Hare, J.A., Holt, J., Ito, S., Kim, S., King, J.R., Loeng, H., MacKenzie, B.R., Mueter, F.J., Okey, T.A., Peck, M.A., Radchencko, V.I., Rice, J.C., Schirripa, M.J., Yatsu, A. \& Yamanaka, Y. 2013. Projected impacts of climate change on marine fish and fisheries. ICES Journal of Marine Science 70(5): 1023-1037.

Hosmer, D.W. \& Lemeshow, S. 2000. Applied Logistic Regression. 2nd ed. New York: John Wiley \& Sons, Inc. pp. 1-383.

Hughes, T.P., Baird, A.H., Bellwood, D.R., Card, M., Connolly, S.R., Folke, C., Grosberg, R., Hoegh-Guldberg, O., Jackson, J.B.C., Kleypas, J., Lough, J.M., Marshall, P., Nyström, M., Palumbi, S.R., Pandolfi, J.M., Rosen, B. \& Roughgarden, J. 2003. Climate change, human impacts, and the resilience of coral reefs. Science 301(5635): 929-933.

IPCC. 2014a. Climate Change 2014: Impacts, Adaptation, and Vulnerability. Part A: global and sectoral aspects. Contribution of working group II to the Fifth assessment report of the intergovernmental panel on climate change. Cambridge, UK and New York, USA: Cambridge University Press.

IPCC. 2014b. Climate Change 2014: Impacts, Adaptation, and Vulnerability. Part B: regional aspects. Contribution of working group II to the fifth assessment report of the intergovernmental panel on climate change. Cambridge, UK and New York, USA: Cambridge University Press.

James, G., Witten, D., Hastie, T. \& Tibshirani, R. 2013. An Introduction to Statistical Learning Vol. 6. New York: Springer. pp. 1-441.

Lam, V.W.Y., Allison, E.H., Bell, J.D., Blythe, J., Cheung, W.W., Frölicher, T.L., Gasalla, M.A. \& Sumaila, U.R. 2020. Climate change, tropical fisheries and prospects for sustainable development. Nature Reviews Earth and Environment 1(9): 440-454.

Lasram, F.B.R. \& Mouillot, D. 2009. Increasing southern invasion enhances congruence between endemic and exotic Mediterranean fish fauna. Biological Invasions 11(3): 697711.

Lehodey, P., Senina, I., Calmettes, B., Hampton, J. \& Nicol, S. 2012. Modelling the impact of climate change on Pacific skipjack tuna population and fisheries. Climate Change 119(1): 95-109.

Leathwick, J.R., Elith, J., Francis, M.P., Hastie, T. \& Taylor, P. 2006. Variation in demersal fish species richness in the oceans surrounding New Zealand: An analysis using boosted regression trees. Marine Ecology Progress Series 321: $267-281$. 
Mansor, M., Abdullah, S. \& Hamid, A. 1996. Population Structure of Small Pelagic Fisheries Off the East Coast of Peninsular Malaysia. Malaysia: Department of Fisheries Malaysia. Ministry of Agriculture. pp. 1-27.

Nadira, Y.K., Mustapha, M.A. \& Ghaffar, M.A. 2019. The Indian mackerel aggregation areas in relation to their oceanographic conditions. Sains Malaysiana 48(11): 25752581 .

Nurdin, S., Mustapha, M.A., Lihan, T. \& Zainuddin, M. 2017. Applicability of remote sensing oceanographic data in the detection of potential fishing grounds of Rastrelliger kanagurta in the archipelagic waters of Spermonde, Indonesia. Fisheries Research 196: 1-12.

Palenzuela, J.M.T., Mar, S.C., Jaime, P.F. \& Monica, M.L. 1998. Sea surface temperature and chloropyll-a correlation study. Thesis. Universidad de Vigo (Unpublished).

Perry, A.L., Low, P.J., Ellis, J.R. \& Reynolds, J.D. 2005. Climate change and distribution shifts in marine fishes. Science 308(5730): 1912-1915.

Phillips, S.J. \& Dudík, M. 2008. Modelling of species distributions with Maxent: New extensions and a comprehensive evaluation. Ecography 31(2): 161-175.

Raja Bidin, R.H. \& Ku Kassim, K.Y. 2007. Information Collection for Sustainable Pelagic Fisheries in the South China Sea. Volume 1. National Country Report. p. 358.

Rapport, D.J., Costanza, R. \& McMichael, A.J. 1998. Assessing ecosystem health. Trends in Ecology and Evolution 13(10): 397-402.

Sabatés, A., Martín, P. \& Raya, V. 2012. Changes in life-history traits in relation to climate change: Bluefish (Pomatomus saltatrix) in the Northwestern Mediterranean. ICES Journal of Marine Science 69(6): 1000-1009.

SEAFDEC. 2017. Southeast Asian State of Fisheries and Aquaculture 2017. Bangkok, Thailand: Southeast Asian Fisheries Development Center. p. 167.

Shaari, N.R. \& Mustapha, M.A. 2018. Predicting potential Rastrelliger kanagurta fish habitat using MODIS data and GIS modelling: A case study of exclusive economic zone, Malaysia. Sains Malaysiana 47(7): 1369-1378.

Simpson, S.D., Jennings, S., Johnson, M.P., Blanchard, J.L., Schön, P.J., Sims, D.W. \& Genner, M.J. 2011. Continental shelf-wide response of a fish assemblage to rapid warming of the sea. Current Biology 21(18): 1565-1570.

Skjoldal, H.R., Dalpadado, P. \& Dommasnes, A. 2004. Food webs and trophic interactions. In The Norwegian Sea Ecosystem, edited by Skjoldal, H.R. Trondheim: Tapir Academic Press. pp. 447-506.

Solanki, H.U., Dwivedi, R.M., Nayak, S.R., Naik, S.K., John, M.E. \& Somvanshi, V.S. 2005. Cover: Application of remotely sensed closely coupled biological and physical process for marine fishery resources exploration. International Journal of Remote Sensing 26(10): 2029-2034.

Sumaila, U.R., Cheung, W.W.L., Lam, V.W.Y., Pauly, D. \& Herrick, S. 2011. Climate change impacts on the biophysics and economics of world fisheries. Nature Climate Change 1(9): 449-456.
Tan, C.K., Shattri, M., Ibrahim, H.M. \& Abdul, R. 2002. Studies of sea surface temperature and chloropyhll-a variations in east coast of Peninsular Malaysia. Pertanika Journal of Science \& Technology 10(1): 13-24.

Tang, D.L., Kawamura, H., Lee, M. \& Van Dien, T. 2003. Seasonal and spatial distribution of chlorophyll-a concentrations and water conditions in the Gulf of Tonkin, South China Sea. Remote Sensing of Environment 85(4): 475-483.

Tseng, C.T., Sun, C.L., Yeh, S.Z., Chen, S.C., Su, W.C. \& Liu, D.C. 2011. Influence of climate-driven sea surface temperature increase on potential habitats of the Pacific saury (Cololabis saira). ICES Journal of Marine Science 68(6): 1105-1113.

Vivekanandan, E. 2013. Climate change: Challenging the sustainability of marine fisheries and ecosystems. Journal of Aquatic Biology and Fisheries 1(1\&2): 54-67.

Vivekanandan, E. 2011. Climate Change and Indian Marine Fisheries. Kochi, India: Central Marine Fisheries Research Institute. pp. 1-97.

Weimerskirch, H., Louzao, M., de Grissac, S. \& Delord, K. 2012. Changes in wind pattern alter albatross distribution and lifehistory traits. Science 335(6065): 211-214.

Yusop, S.M., Mustapha, M.A. \& Lihan, T. 2021. Determination of spatio-temporal distribution of Rastrelliger kanagurta using modelling techniques for optimal fishing. Journal of Coastal Conservation 25(1): 1-7.

Zainuddin, M., Saitoh, K. \& Saitoh, S.I. 2008. Albacore (Thunnus alalunga) fishing ground in relation to oceanographic conditions in the western North Pacific Ocean using remotely sensed satellite data. Fisheries Oceanography 17(2): 61-73.

Kamaruzzaman, Y.N. \& Mustapha, M.A.*

Department of Earth Sciences and Environment

Faculty of Science and Technology

Universiti Kebangsaan Malaysia

43600 UKM Bangi, Selangor Darul Ehsan

Malaysia

Kamaruzzaman, Y.N.

Faculty of Fisheries and Food Science

Universiti Malaysia Terengganu

21300 Kuala Terengganu, Terengganu Darul Iman Malaysia

Ghaffar, M.A.

Institute of Marine Biotechnology

Universiti Malaysia Terengganu

21300 Kuala Terengganu, Terengganu Darul Iman Malaysia

*Corresponding author; email: muzz@ukm.edu.my

Received: 23 October 2020

Accepted: 18 March 2021 